\title{
Spatial distribution of insecticide resistance in Caribbean populations of Aedes aegypti and its significance
}

\author{
Samuel C. Rawlins ${ }^{1}$
}

ABSTRACT To monitor resistance to insecticides, bioassays were performed on 102 strains of the dengue vector Aedes aegypti (L.) from 16 countries ranging from Suriname in South America and through the chain of Caribbean Islands to the Bahamas, where the larvicide temephos and the adulticide malathion have been in use for 15 to 30 years. There was wide variation in the sensitivity to the larvicide in mosquito populations within and among countries.

Mosquito strains in some countries such as Antigua, St. Lucia, and Tortola had consistently high resistance ratios ( $R R)$ to temephos, ranging from 5.3 to 17.7. In another group of countries-e.g., Anguilla and Curaçao-mosquitoes had mixed levels of resistance to temephos $(R R=2.5-10.6)$, and in a third group of countries, including St. Kitts, Barbados, Jamaica, and Suriname, mosquitoes had consistently low levels of resistance to temephos $(R R=1-4.6)(\mathrm{P}<$ 0.05). On occasion significantly different levels of resistance were recorded from neighboring A. aegypti communities, which suggests there is little genetic exchange among populations.

The impact of larval resistance expressed itself as reduced efficacy of temephos to kill mosquitoes when strains were treated in the laboratory or in the field in large container environments with recommended dosages. Although a sensitive strain continued to be completely controlled for up to 7 weeks, the most resistant strains had $24 \%$ survival after the first week. By week $6,60 \%$ to $75 \%$ of all resistant strains of larvae were surviving the larval period.

Responses to malathion in adult A. aegypti varied from a sensitive population in Suriname $(R R=1.3)$ to resistant strains in St. Vincent $(R R=4.4)$, Dominica $(R R=4.2)$, and Trinidad $(R R=4.0)$; however, resistance was generally not on the scale of that observed to temephos in the larval stages and had increased only slightly when compared to the levels that existed 3 to 4 years ago.

Suggestions are made for a pesticide usage policy for the Caribbean region, with modifications for individual countries. This would be formulated based on each country's insecticideresistance profile. Use of physical and biological control strategies would play a more critical role than the use of insecticides.

Aedes aegypti (L.), the only known vector of dengue, dengue hemorrhagic fever, and dengue shock syndrome in the Caribbean as well as a potential vector of urban yellow fever, has continued to wreak havoc in the region by

\footnotetext{
1 Caribbean Epidemiology Centre, Port of Spain, Trinidad. Mailing address: P.O. Box 114, Port of Spain, Trinidad.
}

visiting nearly every country where there have been outbreaks of dengue in the past 3 years $(1,2)$. In an environment where four dengue serotypes are endemic (1-3), the virus and its vector A. aegypti (4-6) challenge the wellbeing of the Caribbean people as well as the vital tourist trade on which nearly all countries rely. Appropriately, public health authorities have advocated managing this mosquito at its source by eliminating containers that harbor $A$. aegypti; in the case of nondisposable containers (7), chemical intervention in the form of insecticide use has been recommended and instituted in most Caribbean member countries of the Caribbean Epidemiology Centre (CAREC), or CMCs.

The pattern of insecticide use for management of $A$. aegypti has been relatively uniform throughout the 
TABLE 1. Insecticide usage for Aedes aegypti control in selected Caribbean countries

\begin{tabular}{lccc}
\hline \multicolumn{3}{c}{ Country } & \multicolumn{3}{c}{ History of insecticide use } \\
\cline { 2 - 4 } \multicolumn{1}{c}{$\begin{array}{c}\text { Temephos } \\
\text { (years of use) }\end{array}$} & $\begin{array}{c}\text { Frequency of } \\
\text { temephos use (per year) }\end{array}$ & $\begin{array}{c}\text { Malathion } \\
\text { (years of use) }\end{array}$ \\
\hline Anguilla & 17 & 1 & 17 \\
Antigua & 15 & $1-2$ & 15 \\
Barbados & bomica & $2-3$ & 20 \\
Dominica & 30 & 2 & 20 \\
Grenada & 15 & $2-3$ & 15 \\
Guyana & 20 & Sporadic & 20 \\
Jamaica & 25 & Sporadic & 20 \\
Netherlands Antilles & 20 & $2-3$ & 20 \\
St. Kitts & 18 & 2 & 15 \\
St. Lucia & 30 & 7 & 30 \\
St. Vincent & 20 & $3-4$ & 20 \\
Suriname & 20 & Sporadic & 20 \\
Tortola & 30 & 4 & 30 \\
Trinidad & 20 & $3-4$ & 20 \\
\hline
\end{tabular}

${ }^{a}$ Frequency of malathion use was sporadic in all countries.

${ }^{b}$ Fenthion was also used.

Caribbean for the past $18-20$ years $(8$, 9). The organophosphorus (OP) insecticides temephos (larvicide) and malathion (adulticide) have been the mainstay of A. aegypti control and dengue prevention for some 20-30 years in CMCs (Tables 1 and 2). With its low toxicity in mammals, the larvicide temephos (Abate), with 1\% sand-core granules, has been accepted for use even in potable water throughout the subregion, with apparent success. Conversely, malathion has been used as an adulticide in thermal fogging or in ultra-low volume, principally in times of high prevalence of mosquitoes or during an outbreak of dengue (9).

Although use of adulticides has been sporadic in the Caribbean-at times of dengue outbreaks or when there are large numbers of annoying mosquitoes-larvicides have been ap- plied to wet containers with a frequency of one to four times per year and up to seven times in one country (Tables 1 and 2). Such frequent use of insecticides may have resulted in the selection of insecticide-resistant populations in some Caribbean countries $(8-10)$. What was not altogether clear, however, was the extent (in countries) of such resistance and its significance in terms of the failure to control A. aesypti which may have accompanied the emergence of insecticide resistance.

Mekuria et al. (10) considered the problem of resistance of $A$. aegypti in the Dominican Republic to be serious enough to warrant considering control measures other than the use of pesticides. Rawlins et al. $(11,12)$ reported on the recommendation of the use of predaceous fish and copepods in some instances when source reduction or pesticide use was no longer practicable or useful.

This report reviews in detail the prevalence of temephos resistance in larval populations and of malathion resistance in adult populations of $A$. aegypti from 16 Caribbean countries. The impact of reduced control of the vector in connection with increased resistance is also evaluated. The present studies form part of a continuing resistance survey reported by Rawlins and

TABLE 2. Organophosphate insecticides used in selected Caribbean countries in 1993 for Aedes aegypti control ${ }^{\text {a }}$

\begin{tabular}{|c|c|c|c|c|c|c|}
\hline Country & $\begin{array}{c}\text { Temephos } \\
\text { 1\% S.G. } \\
\text { (kg) }\end{array}$ & $\begin{array}{c}\text { Temephos } \\
50 \% \text { T.G. } \\
\text { (L) }\end{array}$ & $\begin{array}{c}\text { Malathion } \\
96 \% \text { T.G. } \\
\text { (L) }\end{array}$ & $\begin{array}{c}\text { Malathion } \\
57 \% \text { E.C. } \\
\text { (L) }\end{array}$ & $\begin{array}{l}\text { Malathion } \\
50 \% \text { W.P. } \\
\quad(\mathrm{kg})\end{array}$ & Other OPs \\
\hline Barbados & 175 & 18 & 246 & 0 & 0 & $475 \mathrm{~kg}$ of fenthion $40 \%$ W.P. \\
\hline Dominica & 105 & 0 & 26 & 0 & 90 & 150 L pirimiphos-ethyl (Actellic) \\
\hline Grenada & 2 & 0 & 37 & 0 & 50 & \\
\hline Jamaica & 38 & 0 & 3285 & 0 & 0 & \\
\hline St. Kitts and Nevis & 327 & 0 & 49 & 0 & 0 & \\
\hline St. Lucia & 2948 & 0 & 832 & 0 & 0 & $204 \mathrm{~kg}$ of $5 \%$ temephos \\
\hline St. Vincent & 0 & 0 & 132 & 151 & 0 & \\
\hline Suriname & 154 & 0 & 3600 & 0 & 0 & \\
\hline Tortola & 0 & 0 & 0 & 0 & 0 & \\
\hline Trinidad and Tobago & 1250 & 0 & 4800 & 0 & 5150 & \\
\hline
\end{tabular}

a As reported by vector control units of Ministries of Health.

S.G. $=$ sand granules; T.G. $=$ technical grade; E.C. $=$ emulsifiable concentrate; W.P. $=$ wettable powder; NA = no data available from Bahamas, Guyana, and Montserrat. 
Hing Wan (9) following a report by Georghiou et al. (8). In both studies there was limited geographic diversity of the populations assayed for the prevalence of resistance in each country surveyed. Sometimes only one strain per country was assayed. In this report, attempts are made to determine how widespread (in each country) is the phenomenon of resistance among $A$. aegypti populations and to measure the reduced efficacy of insecticidal treatment in selected strains of the mosquito.

\section{MATERIALS AND METHODS}

\section{Laboratory studies}

One hundred and two strains of $A$. aegypt $i$ were collected for these studies from $16 \mathrm{CMC}$ ranging from Suriname in South America across the chain of islands to the Bahamas in the north. Eggs of each strain-ranging from 200 to 400 per population-were collected from enhanced ovitraps (13) and bioassayed for insecticide resistance at CAREC. This was done between April 1995 and August 1996. Attempts were made to sample a wide spatial variety of $A$. aegypti populations in each country and also to sample populations that previously had been assayed and described (9). Sometimes it was not possible to obtain $A$. aegypti eggs from the precise locations as required.

Also, a known insecticide-sensitive strain from Trinidad, the CAREC strain $(8,9)$, which had been kept at CAREC for 16 years without exposure to any chemicals, was used as the susceptible reference strain. Susceptibility tests were run on $\mathrm{F}_{2}$ to $\mathrm{F}_{4}$ generations.

Standard larvicidal and adulticidal kits and procedures were used for testing insecticide resistance in mosquitoes $(14,15)$. In larvicidal studies, three replicates of 24 fourth instar Aedes larvae were exposed to different concentrations of temephos, malathion, chlorpyrifos, fenitrothion, or fenthion. Only the results of the temephos studies (performed with larvae) are reported here. Mortalities were determined after a 24-hour exposure, and the re- sults were probit analyzed (16). The resistance ratios (RRs) were determined by comparison with the reference CAREC strain. The tests for each strain were repeated at different times.

An analysis of variance was performed on the larval RR data, and the means were further analyzed by Fisher's least-significant difference (LSD) for pairwise comparisons.

Blood-fed females (2-4 days old) were exposed for various periods of time to surfaces impregnated with 5\% malathion (15). They were then kept for $24 \mathrm{~h}$ on insecticide-free surfaces, after which mortality was calculated. The data from at least three replicate experiments were probit analyzed to provide $\mathrm{LT}_{50}$ and $\mathrm{LT}_{90}{ }^{2}$ values, which were compared with those of the reference CAREC strain to obtain RR values for each strain.

These were calculated as follows:

$$
\begin{aligned}
& \mathrm{LC}_{90} \text { or } \mathrm{LT}_{90} \text { for } \\
& \mathrm{RR}=\frac{\text { a particular strain }}{\mathrm{LC}_{90} \text { or } \mathrm{LT}_{90} \text { for the }}
\end{aligned}
$$

where $\mathrm{LC}_{90}$ is the concentration that is lethal to $90 \%$ of the mosquitoes. Larval populations also were assayed at $0.02 \mathrm{mg} / \mathrm{L}$ - the diagnostic dosage for temephos recommended by $\mathrm{WHO}-$ and mortality for the various strains was recorded. For a country profile, the mean RRs for all the populations assayed and the mortalities recorded from the diagnostic dosages were summarized.

\section{Field studies}

Tests were designed to detect whether the observed resistance to temephos in $A$. aegypti larvae was likely to result in failure of control operations depending on the use of standard dosages of temephos at 1 part per million (ppm) in a 200-L drum envi-

\footnotetext{
$2 \mathrm{LT}_{50}$ and $\mathrm{LT}_{90}$ are the times in minutes required to kill $50 \%$ and $90 \%$ of the mosquitoes resting on the insecticide-impregnated surfaces.
}

ronment. The following strains were selected for the study:

$\begin{array}{cl}\text { Most resistant } & \text { Long Look (Tortola), } \\ & \mathrm{RR}=14.8 \\ \begin{array}{c}\text { Moderately } \\ \text { resistant }\end{array} & \text { Calliaqua II (St. Vincent), } \\ \text { Less resistant } & \text { Keartons (St. Vincent), } \\ & \mathrm{RR}=5.0 \\ \text { Susceptible } & \text { CAREC (Trinidad), RR = 1 }\end{array}$

Newly hatched (first instar) Aedes larvae from each strain were counted into groups of 100 and added to drums containing $200 \mathrm{~L}$ of water treated with temephos at $1 \mathrm{ppm}$. There were three replicates per strain. A CAREC control (exposed to no insecticide) was also maintained in three replicates. The drums were covered with mesh to prevent entry or exit of any mosquitoes and to reduce the risk of early emergence and escape. After 4 days, all the surviving and dead Aedes larvae/ pupae were extracted from the drums with a sweep net and counted. The study was extended over an 8-week period. Each week, new first larval instars were added, and at the end of the week percentage survival was calculated. Survivors were detected in the susceptible CAREC strain after about 8 weeks, and the study was halted.

No attempt was made to protect treated drums from rainfall or direct sunlight. During the 8-week period there was a mean daily temperature range of $25{ }^{\circ} \mathrm{C}$ to $33{ }^{\circ} \mathrm{C}$ and a mean daily rainfall of $5.6 \mathrm{~mm}$ (ranging from 0-46 mm).

\section{RESULTS}

\section{Larvicidal studies}

Because of space limitations, the details of the RR profiles of all 102 strains from 16 countries that were tested from the 1995-1996 A. aegypti collections are not shown in Table 3 . What are shown for each country are the new RRs for locations that were included in the 1992-1993 collections (9) and data on the populations with the highest and the lowest RR values for each country. 
TABLE 3. Variations of resistance ratios (RRs) to temephos, based on CAREC susceptible strain, in selected Caribbean populations of larval Aedes aegypti for 1995-1996, compared with 3 years earlier

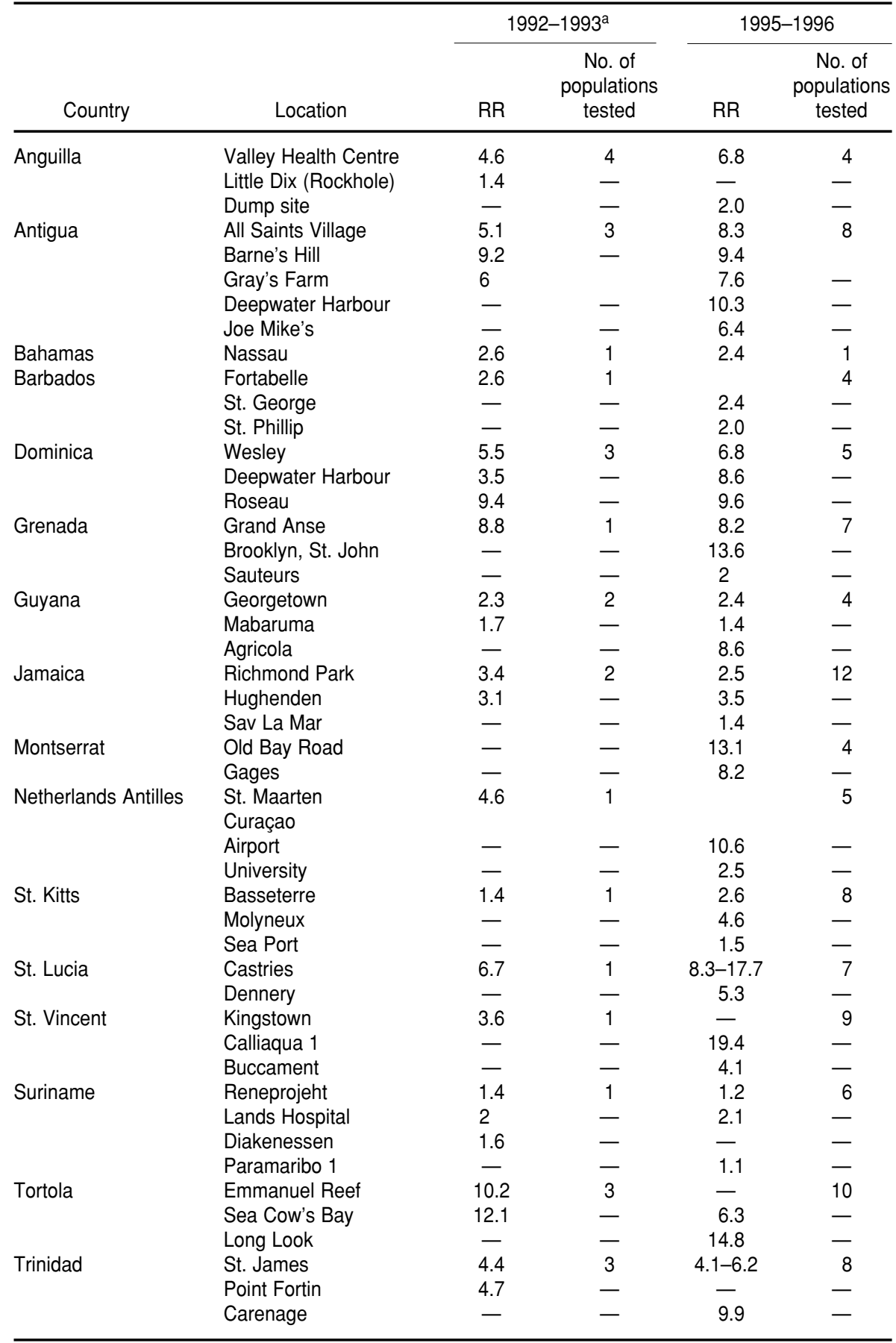

a Data from Rawlins and Hing Wan (9).

Overall, although resistance to temephos appeared to be omnipresent, there were interesting variations in RRs within and among countries (Tables 3 and 4). Within some countries there were consistently high RR values-e.g., Antigua (RR = 6.4-10.3), St. Lucia $(\mathrm{RR}=5.3-17.7)$, and Tortola $(\mathrm{RR}=6.3-14.8)$ (Figure 1). In others, there was a wide range of RRs-e.g.,
Anguilla (RR $=2.0-6.8)$ and Curaçao $(R R=2.5-10.6)$-sometimes even when these populations originated over a relatively small geographic area. In a third scenario, there were low RRs over entire countries for which population data were available for measurement-e.g., Barbados ( $R R=2.0-2.4)$, Jamaica (RR $=1.4-3.5$ ) (from 12 populations), St. Kitts ( $R R=1.6-4.6)$, and Suriname $(R R=1.1-2.1)$. Here, the mean RRs of these five countries were significantly lower $(P<0.05)$ than those of the other countries (Table 4).

Some of these data are presented in Figure 1 for four island countries. It is interesting to note the proximity of the origin of some strains with different RR values. Castries I and Castries II strains (St. Lucia) came from close proximities $(<0.5 \mathrm{~km})$, yet their RRs differed widely: 8.3 and 17.7 , respectively. The moderately resistant Anse La Raye $(R R=5.7)$, Bel Air $(R R=6.6)$, and Bexon $(\mathrm{RR}=7.7)$ populations originated from just about $10 \mathrm{~km}$ away. The Calliaqua I and II strains (St. Vincent $)(R R=10.9-19.4)$ originated just $200 \mathrm{~m}$ from each other, whereas the Golden Vale $(R R=5.5)$ and Brighton $(R R=5.5)$ populations were collected at sites that were separated by only about $1 \mathrm{~km}$. Overall there was some resemblance between RRs for 1992 1993 and those for 1995-1996. There was a general trend toward an increase in resistance when data for these periods were compared.

When the data were summarized to give mean values for countries (Table 4), Tortola $(R R=9.78)$, St. Lucia $(R R=$ 8.9), Dominica ( $R R=8.72)$, and Antigua $(R R=8.30)$ had the highest national means for resistance to temephos $(P<0.05)$. Suriname $(R R=1.48)$, Barbados $(R R=2.24)$, Jamaica $(R R=2.45)$, St. Kitts $(\mathrm{RR}=3.08)$, and Guyana $(\mathrm{RR}=$ 3.60) had A. aegypti populations with the lowest resistance to temephos.

When country RR means were compared with mean mortality caused by the diagnostic dosages (Figure 2), the least resistant $A$. aegypti strain from Suriname $(R R=1.48)$ showed the greatest mortality $(84.08 \%)$, and the severely resistant Tortola strains $(\mathrm{RR}=$ 9.78) experienced a mean mortality of 
TABLE 4. Variation of resistance ratios (RRs) of temephos among Caribbean strains of larval Aedes aegypti, 1995-1996

\begin{tabular}{lrrr}
\hline \multicolumn{1}{c}{ Country } & Strains & Mean RR & SD \\
\hline Antigua & 8 & $8.300 \mathrm{~b}$ & 1.278 \\
Barbados & 5 & $2.240 \mathrm{a}$ & 0.182 \\
Dominica & 5 & $8.720 \mathrm{~b}$ & 1.154 \\
Grenada & 7 & $8.243 \mathrm{~b}$ & 3.577 \\
Guyana & 4 & $3.600 \mathrm{a}$ & 3.359 \\
Jamaica & 12 & $2.450 \mathrm{a}$ & 0.568 \\
Montserrat & 4 & $10.250 \mathrm{~b}$ & 2.102 \\
Netherlands & & & \\
$\quad$ Antilles & 5 & $7.260 \mathrm{~b}$ & 3.475 \\
St. Kitts & 8 & $3.075 \mathrm{a}$ & 0.984 \\
St. Lucia & 7 & $8.943 \mathrm{~b}$ & 4.349 \\
St. Vincent & 9 & $8.111 \mathrm{~b}$ & 4.779 \\
Suriname & 6 & $1.483 \mathrm{a}$ & 0.366 \\
Tortola & 10 & $9.778 \mathrm{~b}$ & 2.827 \\
Trinidad and & & & \\
$\quad$ Tobago & 8 & $5.975 \mathrm{~b}$ & 1.813 \\
\end{tabular}

Fisher LSD for pairwise comparisons (2.653). Country means followed by a different letter indicate statistically significant differences $(P<0.05)$. only $0.30 \%$. Between the two extremes, slight to moderate levels of resistance ( RR $=2-4$ ) gave $47 \%$ to $19 \%$ mortality, and, when treated at the diagnostic dosage, moderate to severely resistant strains ( $R R=4.0-8.9$ ) had only $1.3 \%$ to $18.66 \%$ mortality.

\section{Field studies}

When the severely resistant Long Look (Tortola) population was exposed in the field to drum treatments of 1 ppm of temephos, there was an immediate survival of $24 \%$ (by day 4 ) and 7 days later newly exposed Aedes larvae experienced a survival of $60 \%$, which rose to $80 \% 4$ weeks after the containers were first treated (Figure 3). Similarly, by day 11 the moderately re- sistant Calliaqua (4\%) and the less resistant Keartons (11\%) populations had begun to experience survival at the 1-ppm treatment level. On day 46, the sand granules containing $1 \%$ temephos continued to be completely effective against the susceptible CAREC strain (100\% mortality), whereas the various resistant strains had $45 \%$ to $60 \%$ survival (Figure 3). Later, while the susceptible CAREC strain continued to experience $100 \%$ mortality up to day 53 , the resistant strains showed $70 \%$ to $95 \%$ survival at the 1-ppm dosage.

\section{Adulticide studies}

Resistance data against malathion for adult $A$. aegypti populations from selected Caribbean countries are dis-

FIGURE 1. Spatial distribution of temephos resistance in Aedes aegypti populations in four Caribbean countries. Resistance ratios (RRs) based on CAREC susceptible strain
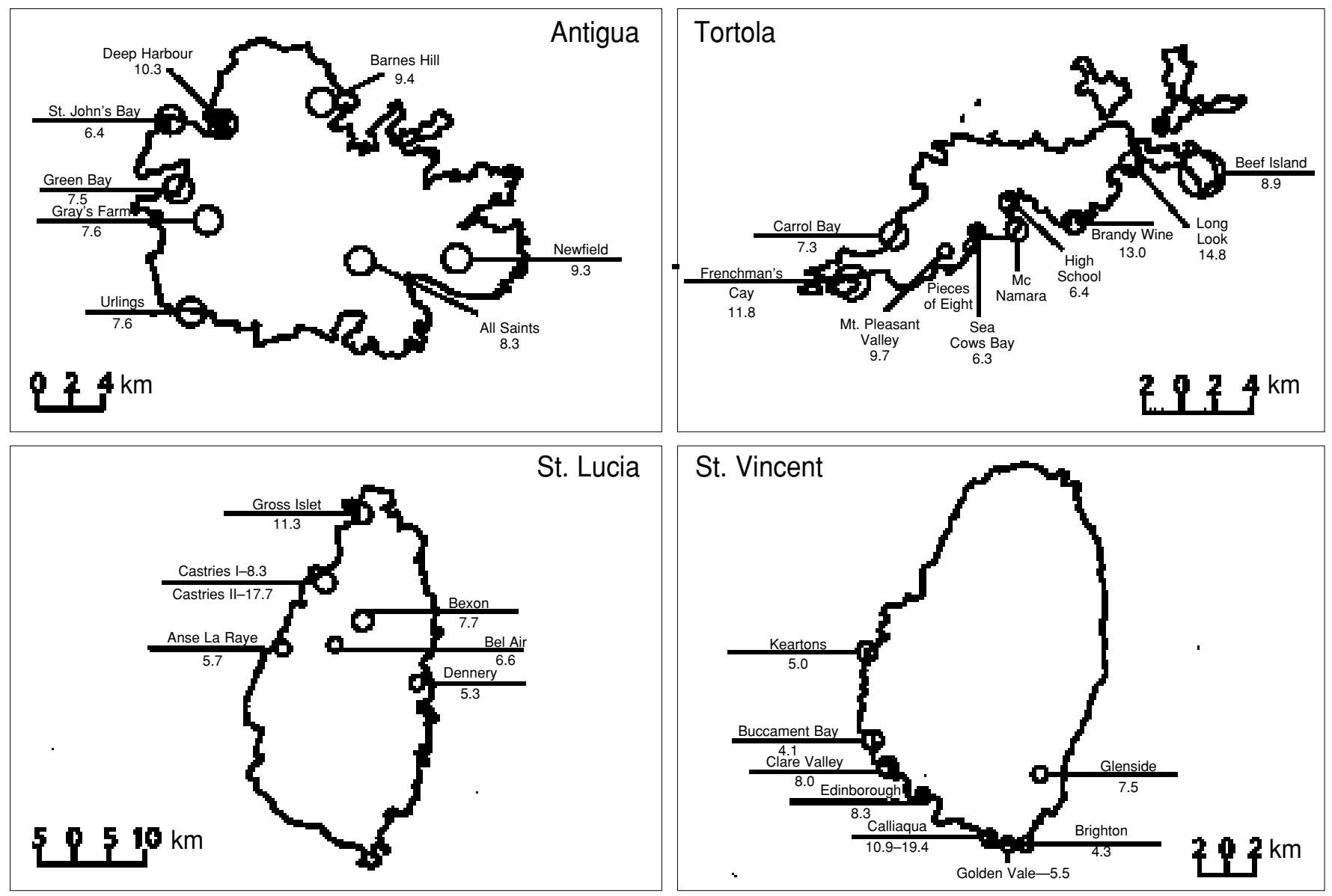
FIGURE 2. Patterns of resistance to temephos in Caribbean strains of Aedes aegypti and mortality due to diagnostic dosages of temephos (1996)

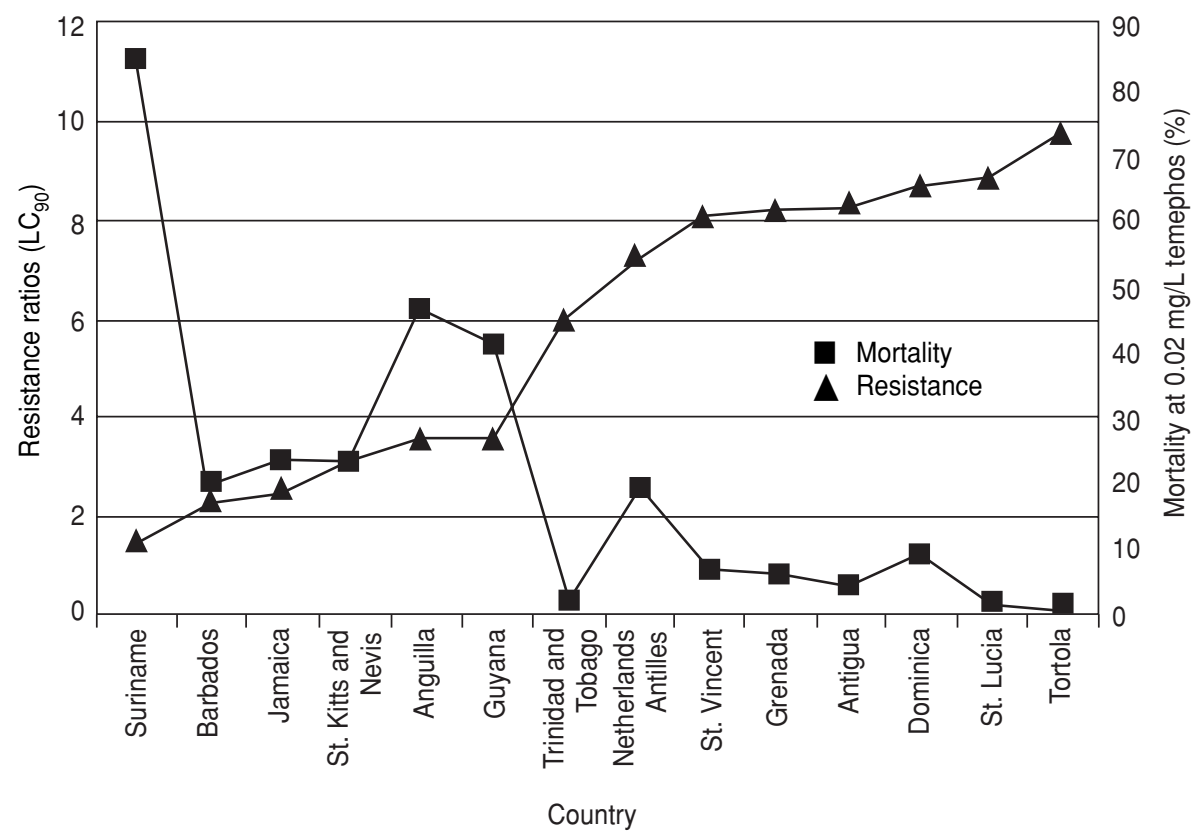

played in Table 5. Data from 19921993 are also displayed for a comparison with 1995-1996 data. The latest figures show varying degrees of susceptibility/resistance, ranging from the susceptible Suriname strain $(\mathrm{RR}=$ 1.3) to the more resistant Trinidad
$(R R=4.0)$, Dominica $(R R=4.2)$, and St. Vincent $(R R=4.4)$ strains. Between these susceptible and resistant strains, the RRs ranged from 1.5 to 3.6: Guyana $(\mathrm{RR}=1.5) ;$ Anguilla $(\mathrm{RR}=1.6) ;$ Antigua $(\mathrm{RR}=2.5)$; Jamaica $(\mathrm{RR}=$ 2.2-3.6); St. Kitts $(R R=2.4-3.5)$.

FIGURE 3. Survival of four strains of Aedes aegypti with various levels of temephos sensitivity in drums treated with temephos at $1 \mathrm{ppm}$

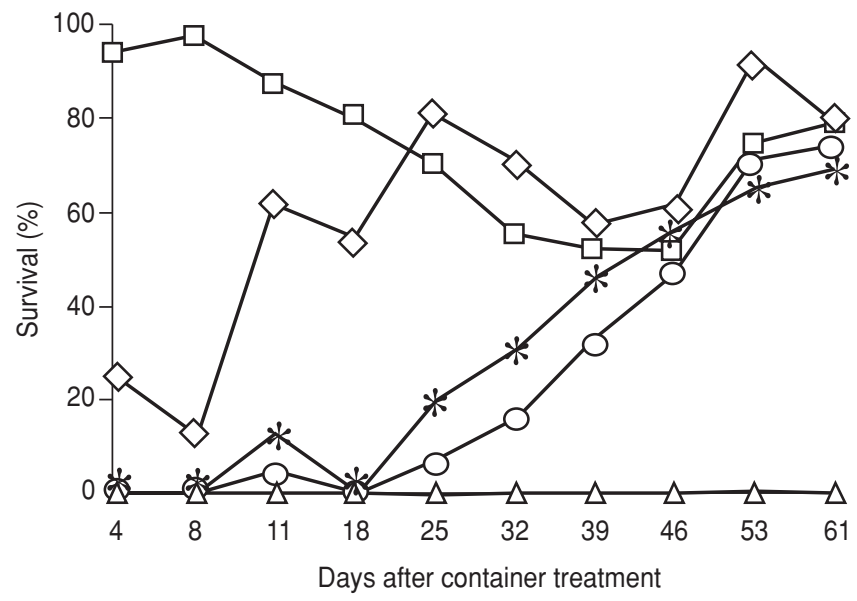

$$
\begin{aligned}
& \checkmark \text { Long Look, } \\
& \text { Tortola, BVI } \\
& * \begin{array}{l}
\text { Keartons, } \\
\text { St. Vincent }
\end{array} \\
& -O-\text { Calliaqua, } \\
& \text { St. Vincent } \\
& -\Delta-\begin{array}{l}
\text { CAREC, } \\
\text { susceptible } \\
\text { treated } \\
\text { strain } \\
- \\
\text { Control, } \\
\text { susceptible } \\
\text { untreated } \\
\text { strain }
\end{array}
\end{aligned}
$$

When these latest data were compared with the earlier (1992-1993) RR data, there were slight increases overall, indicating ongoing selection of more resistance to malathion in the various adult $A$. aegypti populations. There was no apparent correlation between larval and adult resistance for the populations in the various countries.

\section{DISCUSSION}

The data indicate the omnipresence of resistance to temephos in Caribbean populations of $A$. aegypti and confirm the results of previous reports, such as those of Georghiou et al. (8) and Rawlins and Hing Wan (9). However, a detailed spatial study such as this is justified because the variations of resistance within and among countries will recommend various control strategies, which may be peculiar to a given country.

In an environment that is favorable to the proliferation of $A$. aegypti throughout the year, there may be 15 to 17 generations in one year and, with exposure of survivors to temephos over a period of 20 to 30 years, it is not surprising that resistance to this insecticide has appeared. However, temephos has been a convenient insecticide because of its low oral toxicity in mammals $(8600 \mathrm{mg} / \mathrm{kg}$ in male rats), and it is one of the few insecticides recommended for use in potable water (5). Also, because of its relatively low price as compared to some of the newer pyrethroids, it has been difficult to withdraw the recommendation for using temephos to control container breeding of mosquitoes.

For the past few years, source reduction and abandoning the use of larvicides in the Caribbean have been recommended except in habitats that are absolutely not disposable, because the public water supply may sometimes be unreliable (7). Even so, the use of biological control tools, such as guppies and copepods, has been recommended for control of $A$. aegypt $i$ in some circumstances $(11,12)$. Still, temephos continues to be used in Caribbean countries because of tradition and because of the 
TABLE 5. Variations of resistance ratios (RRs) to malathion, based on CAREC susceptible strain, in selected Caribbean populations of adult Aedes aegypti for 1995-1996, compared with 3 years earlier

\begin{tabular}{|c|c|c|c|c|c|}
\hline \multirow[b]{2}{*}{ Country } & \multirow[b]{2}{*}{ Location } & \multicolumn{2}{|c|}{$1992-1993^{a}$} & \multicolumn{2}{|c|}{$1995-1996$} \\
\hline & & $\mathrm{RR}$ & $\begin{array}{l}\text { Populations } \\
\text { tested }\end{array}$ & $\mathrm{RR}$ & $\begin{array}{l}\text { Populations } \\
\text { tested }\end{array}$ \\
\hline \multirow[t]{3}{*}{ Anguilla } & The Valley & 0.7 & 4 & - & 1 \\
\hline & Crocus Bay & 1.1 & & - & \\
\hline & Valley Health Centre & 0.9 & & 1.6 & \\
\hline \multirow[t]{2}{*}{ Antigua } & All Saints Village & 1.3 & 4 & 2.5 & 1 \\
\hline & Urlings & 3.0 & & - & \\
\hline Bahamas & Nassau & 1.0 & 1 & 3.4 & 1 \\
\hline \multirow[t]{3}{*}{ Barbados } & Fontabelle & 2.6 & 1 & - & 2 \\
\hline & St. George & 1.2 & & 3.6 & \\
\hline & Christ Church & - & & 3.3 & \\
\hline \multirow[t]{4}{*}{ Dominica } & Roseau Harbour & 2.5 & 4 & - & 2 \\
\hline & Canefield Airport & 1.2 & & - & \\
\hline & Mahaut Hill & - & & 4.2 & \\
\hline & Scott's Head & - & & 3.1 & \\
\hline \multirow[t]{2}{*}{ Guyana } & Mabarauma & 1.5 & 2 & 1.5 & 1 \\
\hline & Georgetown & 1.7 & & - & \\
\hline \multirow[t]{2}{*}{ Jamaica } & Hughenden & 4.0 & 2 & 3.6 & 12 \\
\hline & Richmond Park & 2.8 & & 2.2 & \\
\hline \multirow[t]{3}{*}{ Montserrat } & Plymouth & 2.7 & 1 & - & 3 \\
\hline & Ft. Barrington & - & & 3.0 & \\
\hline & Factory site & - & & 2.1 & \\
\hline \multirow[t]{2}{*}{ St. Kitts } & Basseterre & 1.7 & 1 & 2.4 & 4 \\
\hline & Sea port & - & & 3.5 & \\
\hline \multirow[t]{2}{*}{ St. Lucia } & Castries & 3.3 & 1 & 3.6 & 2 \\
\hline & Anse La Raye & - & & 2.7 & \\
\hline \multirow[t]{2}{*}{ St. Vincent } & Kingston & 2.1 & 1 & - & 1 \\
\hline & Calliaqua & - & & 4.4 & \\
\hline \multirow[t]{4}{*}{ Suriname } & Diakenessen & 1.0 & 3 & - & 3 \\
\hline & Lands Hospital & 2.4 & & - & \\
\hline & Paramaribo & - & & 3.4 & \\
\hline & Moengo & - & & 1.3 & \\
\hline \multirow[t]{2}{*}{ Tortola } & Emmanuel Reef & 3.1 & 2 & - & 1 \\
\hline & Sea Cow's Bay & 2.1 & & 2.0 & \\
\hline \multirow[t]{3}{*}{ Trinidad } & St. James & 3.8 & 3 & 1 & 4 \\
\hline & Caroni & 2.6 & & - & \\
\hline & Mucurapo & - & & - & \\
\hline
\end{tabular}

${ }^{a}$ Data for 1992-1993 from Rawlins and Hing Wan (9).

convenience of using the sand-granule formulation. Where communities cease to use this "valuable" insecticide, it is possible that reversal of susceptibility to the chemical may occur, as Keiding (17) suggested, thus providing a possible future role for temephos.

According to the data, once resistance in A. aegypti has been selected for in small island populations such as Tortola, Antigua, St. Lucia, St. Vincent, and Dominica, it is maintained at a fairly high level despite the fact that the insect vector control divisions in some of these countries have not recommended the use of larvicides for the past $2-3$ years. Although currently low in their resistance to temephos, $A$. aegypti populations on other small islands, such as St. Kitts and Anguilla, are probably on their way to becoming highly resistant to it. To prevent this from happening, we recommend that the insecticide be withdrawn at once.

In larger land masses and mainland countries, such as Guyana, Jamaica, and Suriname, A. aegypti populations have shown only low levels of resis- tance to the larvicide. This may have been due to a genetic dilution factor, which may prevent development and rapid spread of resistance to susceptible populations. Conversely, the cause may have been the irregular, sporadic use of the larvicide in those communities.

Of significant interest, however, is the mechanism of spread of genetic material that permits distribution of resistance from one community to another. Communities that are nearly adjacent to one another may have significantly different resistance profiles. Examples are the Castries I $(R R=8.3)$ and II (RR = 17.7) of St. Lucia. Similarly, in the village of Calliaqua in southern St. Vincent, populations separated by as little as $0.5 \mathrm{~km}$ exhibited RRs of 10.9 and 19.4, while the nearby populations of Golden Vale $(R R=5.5)$ and Brighton $(R R=4.3)$ remained only moderately resistant. Miscegenation and hybridization of $A$. aegypti strains appear to be slow processes. Perhaps dispersal driven by oviposition needs as reported by Reiter et al. (18) is not as significant as it may appear and $A$. aegypti remains as discrete populations; it is thus possible that populations in adjacent areas may have different insecticide-resistance characteristics.

There was good correlation between RR values and survival of $A$. aegypti populations after treatment with diagnostic dosages. In this respect, vector control staff with minimum skills, equipment, and materials could feasibly predict the usefulness of insecticides by testing at the diagnostic dosage level. Survival would be of practical value in indicating the onset of resistance.

Drum habitat studies indicated the futility of attempting to use larvicides once resistance has emerged. Although the CAREC susceptible population was controlled over 6-7 weeks with $100 \%$ mortality, from week 1 the Long Look strain (resistant Tortola strain) showed good survival. This makes the case for abandoning chemicals once resistance is proven. Fortunately, other OP insecticides, such as malathion and fenitrothion, continue to be effective against these temephos- 
resistant populations (S. C. Rawlins, unpublished data, 1997). The conflict arises, however, because these other OPs are not recommended for potable water. This brings us back to source reduction and biological control for management of $A$. aegypti larvae.

\section{Adult resistance}

The data indicate that in most countries of the Caribbean there are only low levels of resistance to the adulticide malathion, which has been in sporadic use for 20 to 30 years. Only in the St. Vincent, Dominica, and Trinidad populations were RRs $>4$. Given the sporadic usage in emergency situations, unlike the case in larvicidal treatment, there has not been a consistently applied selection pressure for the emergence of resistant populations; consequently, this chemical can continue to be useful if there is an appropriate means of delivery to the adult's habitat. Recent experience with the aerial treatment of Jamaican A. aegypti with malathion indicated failure to control a population with little resistance $(R R=2.5)$, probably because of faulty delivery of the adulticide (19). However, modifying its applications could result in improved efficacy of the adulticide.

\section{Pesticide use policy}

What is needed in the Caribbean region at this time is a comprehensive policy on insecticide use against Aedes aegypti based on knowledge of the insecticide-resistance status of the various geographic units of the CMCs. There needs to be access to a greater variety of insecticides, with a system that monitors the use of diagnostic dosages so that the communities can detect any loss of efficacy of the chemicals. The policy also should include rotation systems for switching from one type of insecticide to another, so that selection of resistant populations can be prevented. At the same time, the policy could establish the frequency of applications needed for greater effectiveness. Intradomiciliary treatments carried out by the community with recommended aerosols may become routine, because it is known that truck-mounted or even aircraft- dispensed chemicals do not penetrate households and kill adult mosquitoes very effectively.

A decisive issue in all this is cost. In relatively poor societies, the choice of methods of vector control is limited by the availability of funds, so that less expensive methods of biological and physical control may be more attractive. Creating a culture of reducing sources of container-bred mosquitoes or community involvement in mass producing, distributing, and using biological control tools such as copepods may be the way forward.

Acknowledgments. I am grateful to all vector control personnel in the Caribbean who assisted by contributing strains of Aedes aegypti from the various territories. I am also grateful to my colleagues at CAREC who assisted with the technical work: J. O. Hing Wan, S. Wiltshire, R. Martinez, S. Mahadeo, and M. Morais. The Government of Italy kindly provided funds through the Caribbean Cooperation in Health, and PAHO (Caribbean Program Coordination) supported some of the work.

\section{REFERENCES}

1. Caribbean Epidemiology Centre. Annual report. Port of Spain: CAREC; 1995.

2. Caribbean Epidemiology Centre. Annual report. Port of Spain: CAREC; 1996.

3. Caribbean Epidemiology Centre. Fax alert: Dengue virus type 3 in Puerto Rico. Port of Spain: CAREC; 1998.

4. Nathan MB, Knudsen AB. Aedes aegypti infestation characteristics in several Caribbean countries and implications for integrated community-based control. J Am Mosq Control Assoc 1991;7:400-404.

5. Pan American Health Organization. Dengue and dengue haemorrhagic fever in the Americas: Guidelines for prevention and control. Washington, DC: PAHO; 1994. (Scientific publication 548).

6. Nathan MB. Critical review of Aedes aegypti control programs in the Caribbean and selected neighbouring countries. J Am Mosq Control Assoc 1993;9:1-7.
7. Rosenbaum J, Nathan MB, Ragoonansingh $\mathrm{R}$, Rawlins SC, Gayle C, Chadee DD, et al. Community participation in dengue prevention and control: A survey of knowledge, attitudes and practice in Trinidad and Tobago. Am J Trop Med Hyg 1995;53:111-117.

8. Georghiou GP, Wirth M, Tran H, Saum F, Knudsen AB. Potential for organophosphate resistance in Aedes aegypti in the Caribbean area and neighbouring countries. J Med Entomol 1987;24:290-294.

9. Rawlins SC, Hing Wan JO. Resistance in some Caribbean populations of Aedes aegypti to several insecticides. J Am Mosq Control Assoc 1995;11:59-65.

10. Mekuria Y, Gwinn A, Williams DC, Tidwell MA. Insecticide susceptibility of Aedes aegypti from Santo Domingo, Dominican Republic. J Am Mosq Control Assoc 1991;7:69-72.

11. Rawlins SC, Martinez R, Nimblett A. Consumption of Aedes aegypti larvAedes by Poe- cilia reticulata (guppies) and factors which affect the productivity of the larvivorous fish in drum environments. J Fla Mosq Control Assoc 1993;64:125-128.

12. Rawlins SC, Martinez R, Wiltshire S, Clarke D, Prabhakar P, Spinks M. Evaluation of Caribbean strains of Macrocyclops and Mesocyclops (Cyclopoidae: Cyclopidae) as biological control tools for the dengue vector Aedes aegypti. J Am Mosq Control Assoc 1997;13:18-23.

13. Reiter $\mathrm{P}$, Amador MA, Colon N. Enhancement of the CDC ovitrap with hay infusion for daily monitoring of Aedes aegypti populations. J Am Mosq Control Assoc 1991;7:52-55.

14. World Health Organization. Instructions for determining the susceptibility of mosquito larvAedes to insecticides. Geneva: WHO; 1981. (WHO/VBC/81.807).

15. World Health Organization. Instructions for determining the susceptibility or resistance of adult mosquitoes to organochlorine, organophosphate and 
carbamate insecticides: Establishment of the baseline. Geneva: WHO; 1981. (WHO/VBC/81:805).

16. Finney DJ. Probit analysis: A statistical treatment of the sigmoid curve. Cambridge, UK: Cambridge University Press; 1964.

17. Keiding J. Development of resistance in the field and studies of resistance. Trans 9th Int Congr Entomol 1953;2:340-345.
18. Reiter P, Amador MA, Anderson RA, Clarke GG. Dispersal of Aedes aegypti in an urban area after blood feeding as demonstrated by rubidium-marked eggs. Am J Trop Med Hyg 1995;52:177-179.

19. Castle T, Amador M, Rawlins S, Figueroa JP, Reiter P. Absence of impact of aerial ULV malathion on Aedes aegypti during a dengue fever outbreak in Kingston, Jamaica. West Indian Med J 1997;46:2.

Manuscript received on 15 August 1997. Revised version accepted for publication on 11 August 1998.

RESUMEN Para estudiar su resistencia a los insecticidas, se sometieron a bioensayos 102 cepas del vector del dengue Aedes aegypti (L.) originarias de 16 países que se extienden desde Suriname en Suramérica y la cadena de islas del Caribe hasta las Bahamas. En esos

Distribución espacial e importancia de la resistencia a insecticidas de poblaciones de Aedes aegypti en el Caribe países el larvicida temefós y el adulticida malatión se han usado por un período de 15 a 30 años. La sensibilidad al larvicida varió mucho en las poblaciones de mosquitos dentro de un país y de un país a otro.

En cepas de mosquitos de algunos países como Antigua, Santa Lucía y Tortola, se observaron repetidamente altas razones de resistencia (RR) al temefós, que oscilaron entre 5,3 y 17,7. En los mosquitos de otro grupo de países (Anguila y Curazao), se midieron grados mixtos de resistencia al temefós $(R R=2,5$ a 10,6$)$ y, en un tercer grupo de países, incluidos San Kitts, Barbados, Jamaica y Suriname, los mosquitos tuvieron grados bajos de resistencia al temefós $(\mathrm{RR}=1$ a 4,6$)(P<0,05)$. Se registraron grados de resistencia muy dispares en algunas comunidades contiguas de A. aegypti, lo que indica poco intercambio genético entre poblaciones.

Los efectos de la resistencia larvaria se manifestaron como una reducción de la eficacia del temefós para matar mosquitos cuando las cepas se trataban con las dosis recomendadas en el laboratorio o en grandes recipientes sobre el terreno. Si bien una cepa sensible se siguió controlando completamente hasta por 7 semanas, las cepas más resistentes tuvieron una supervivencia de $24 \%$ al cabo de la primera semana. Para la sexta semana, de 60 a 75\% de las larvas de cepas resistentes sobrevivieron más allá del estadio larvario.

Las respuestas de los mosquitos adultos al malatión variaron, desde la sensibilidad de una población en Suriname $(R R=1,3)$ hasta la resistencia de cepas en San Vicente $(R R=4,4)$, Dominica $(R R=4,2)$ y Trinidad $(R R=4,0)$. Sin embargo, esa resistencia no llegó al grado de la que mostraron las larvas al temefós y aumentó muy poco comparada con los grados de resistencia registrados hace tres o cuatro años.

Se ofrecen recomendaciones para elaborar una política del uso de plaguicidas en la región del Caribe que pueda adaptarse individualmente a los países. Esta se formularía sobre la base del perfil de resistencia a los insecticidas en cada país. Las estrategias de control físicas y biológicas desempeñarían una función más crítica que los insecticidas. 